\title{
The Relationship between Emotional Intelligence and Learners' Beliefs about Language Learning: Iranian Advanced EFL Learners in Focus
}

\author{
Zahra Ghanadi \\ English Language Department, Faculty of Foreign Languages, University of Isfahan, Hezarjarib Street., Isfahan, Iran \\ Saeed Ketabi \\ English Language Department, Faculty of Foreign Languages, University of Isfahan, Hezarjarib Street., Isfahan, Iran
}

\begin{abstract}
The aim of this study was twofold: (1) to see whether there is any significant relationship between emotional intelligence and learners' beliefs about language learning and (2) to examine whether emotional intelligence can predict learners' beliefs about language learning. The participants of this study were 138 undergraduate EFL learners at two universities in Iran. To this end, two self-reported questionnaires including Trait Emotional Intelligence-short form (TELQue-SF) and Beliefs about Foreign Language Inventory (BALLI) were employed to gather the data. Results revealed that there was a positive and significant relationship between emotional intelligence and learners' beliefs about language learning. Furthermore, emotional intelligence can predict learners' beliefs about language learning. The findings could have some implications for EFL teachers and practionairs.
\end{abstract}

Index Terms - emotion, emotional intelligence, belief about language learning, EFL, Iranian learners

\section{INTRODUCTION}

One of the important issues in the realm of education is that to what extent learners' emotions may influence on language learning. Introducing the concept of emotional intelligence is the crucial event in interdisciplinary fields of study especially in the moral education during the last twenty years. Psychologists of education contend that incorporating emotional intelligence (henceforth, EI) is the underlying goal of teaching and learning especially in to the higher education (Cohen, 1999; Vandervoort, 2006). But, there is a lively debate underway within about the effect of integrating emotional intelligence in to academic performance, educational policy and learning environment. Aragao (2011) mentioned that emotions and beliefs, fundamental in life, play an important role in foreign language learning. To date, as of writing this article, no published work has addressed whether emotional intelligence correlates with learners' beliefs about language learning. The major aim of this study is to cover this lacuna by: 1) investigating the relationship between emotional intelligence and learners' beliefs about language learning and also 2) predicting learners' beliefs about language learning by emotional intelligence.

\section{EMOTIONAL INTELLIGENCE}

The concept of emotional intelligence was first put forward by Payne (1986). Then, this concept developed formally by two pioneers in the field of psychology, Salovey and Mayer (1990). Mayer and Salovey (1997) defined emotional intelligence as "the abilities to accurately perceive emotions, to access and generate emotions so as to assist thought, to understand emotions and emotional knowledge, and to reflectively regulate emotions so as to promote emotional and intellectual growth". Emotions as one of the basic elements of emotional intelligence have an outstanding influence on learners' education. Since the inception of emotional intelligence theory (EI), several models were defined and introduced by (Goleman, 1995; Mayer and Salovey, 1997; Bar-On, 1997). Horward psychologist, Daniel Goleman (1995) defined emotional intelligence as "abilities such as being able to motivate oneself and persist in the face of frustration; to control impulses and delay gratification; to regulate one's moods and keep distress from swapping the ability to think; to emphasize and to hope" (p.34). Based on this definition, Goleman (1995) created a model that was combined five essential elements: 1) knowing ones emotion, 2) managing emotions, 3) motivating oneself, 4) recognizing emotions in others, 5) handling relationships. The existence of various models of emotional intelligence. Later, Goleman (1998) reformulated his first definition of emotional intelligence and broke down emotional intelligence into twenty-five different emotional competencies, among them political awareness, service orientation, self-confidence, consciousness, and achievement drive (See Pishghadam, 2009).

Sometimes, educators believe that lack of success in both learners' education and life might be due to the academic intelligences which are measured by IQ tests. Zalesne \& Nadvorney (2011) defined learner's academic intelligence as "about more than simply cognitive skills; it's akin to culture, including not only cognitive, but also affective and social 
skills, all of which contribute to a student' level of success" (p.264). But, Van Der Zee, Thijs \& Schakel (2002) declare that academic intelligence seems not sufficient for everyday problem solving. They state that emotional intelligences are better predictor of success in real life and education than academic intelligence. For two decades, there has been growing interest in investigating the concept of emotional intelligence (EI) in different fields of studies such as mental, social and physical health (Extremera \& Berrocal, 2006; Martins, Ramalho \& Morin, 2010) and task performance (Carmeli \& Josman, 2006). Until recently, emotional intelligence has been the main concern of many educational researchers especially in the field of academic success of second language learners (Stottlemayer, 2002; Petride, Frederickson \& Furnham, 2004). More published studies in this area have been concerned the importance of emotional intelligence in EFL/ESL context. Pishghadam (2009) explored the pivotal role of emotional intelligence in students' academic scores in reading, listening, writing and reading. His studies revealed that second language learning was strongly associated with several dimension of emotional intelligence. In another research attempt, Shao, Yu and Ji (2013) investigated the relationship between EFL students' emotional intelligence and writing achievement among 68 non-English major freshmen in a university in Hang Zhou. They found that there was a relatively strong positive relationship between EI and writing achievement. But yet, more attention has been required to the ways which foreign language learners' emotional intelligence could be raised. Arnold (1999) considered the importance of affect and emotion in the realm of education for two reasons:

1) Attention to affective dimension can lead to more effective language learning

2) This attention to affective factors can even reach beyond language teaching and even beyond what has traditionally been considered the academic realm.

According to Garette and Young (2009) "Affect and emotion are concepts that have been in the shadows of discussion of classroom foreign language learning, where the primary focus has been on the development of knowledge and use of new language" (p.209).

\section{BELIEFS ABOUT LANGUAGE LEARNING}

Conceptualization of learner's beliefs on language learning has been introduced into second language literature by Horwitz (1985, 1987\& 1988). Bernat (2008) asserted that "in the SLA field almost two decades of research has revealed how learners' beliefs have the potential to shape their cognitive and affective processes in the classroom and impact on their actions" (p.1). According to Sakui \& Gaies (1999), Beliefs are central construct in every discipline which deals with human behavior and learning. Based on the definition of beliefs, Barcelos (2003) classified his studies in to three approaches:

The first category of this approach denotes to "Normative Approaches". The normative approach refers to "beliefs about SLA as indicators of students' future behavior as autonomous or good learners". The type of data collection in this approach entails using Likert- type questionnaires ranging from strongly disagree (1) to strongly agree (5). One of long-establishes questionnaire to explore beliefs is Horwitz's (1985) beliefs about language learning inventory (henceforth, BALLI). Since then, many researchers employed and modify this self-report questionnaire in their studies (Yang, 1992; Mantle-Bromley, 1995). The next approach refers to "Metacognitive Knowledge". Wenden (1987) defined metacognitive knowledge as "the stable, sometimes incorrect knowledge that learners acquired about language learning and language learning process" (p.163). According to Wenden (1999) the concept of beliefs in this category is different from knowledge. The methodologies used in the approach encompass both semi-structure interview and selfreport questionnaires. The third and the more recent approach is called "Contextual Approach". The aim of this approach is to get a better understanding of learners' beliefs in specific contexts. Different methods have been adopted including ethnographic classroom observations, diaries and narratives (See Barocel, 2003).

The importance of studying learners' beliefs towards language learning has recently been drew attention of many researchers (Simon \& Taverniers, 2011; Yoshiba, 2013; Fisher, 2013). Miccoli $(1997,2000)$ maintained that "avoiding speaking in class is because of learners' fear of criticism of other classmates along with conceiving the class as a judgmental environment" (Cited in Aragao, 2011, p, 304). These behaviors may be due to learners' beliefs which are influenced by their emotions in learning environment.

Most of the research studies addressed the importance of learners' beliefs in relationship with other variables. Yang (1999) conducted study on 500 Taiwanese learners to investigate the relationship between EFL learners' beliefs about language learning and their use of learning strategies. He found that learners' self-efficacy beliefs about learning English were strongly related to their use of all types of learning strategies. Cheng (2001) explored the relationship between learners' beliefs and language anxiety among 167 EFL students at one university in Taiwan. He found that there was a significant and positive relationship between learners' beliefs and their level of anxiety. Hung and Tasi (2003) investigated the relationship between learners' beliefs and their proficiency level among 89 Taiwance high school students. Their study revealed that high proficiency learners had more positive language learning beliefs than low proficiency learners. In another study, Li and Liang (2012) examined the relationship between EFL learners' beliefs about language learning in and proficiency in a Chinese context. They found that such relationship was existed among these two variables. Despite of the host of findings regarding how to enhance learners' beliefs towards language learning, relatively little attention has been paid to the effect of emotion on learners' beliefs. So, this study aimed to shed more light to explore the relationship between emotional intelligence and learners' beliefs about language learning. 


\section{The Purpose AND Research Questions}

The primary purpose of this study was aimed at investigating whether there is any significant relationship between emotional intelligence and EFL learners' beliefs about language learning. The current study attempts to explore the effect of emotional intelligence in relationship with learners' beliefs about language learning and to examine whether emotional intelligence is the predictor of learners' beliefs bout language learning.

Based on the purpose mentioned above, the following research questions will be addresses in this study:

1. Is there a significant relationship between emotional intelligence and learners' beliefs about language learning?

2. Can emotional intelligence predict learners' beliefs about language learning?

\section{METHOD}

\section{A. Participants}

A total number of 138 senior EFL learners participated in this study, comprised of 92 females and 46 males between the age of 20 and 26. All of the participants were university learners majoring in English language literature and translation. They were all Persian native speakers and have not yet been to an English speaking country.

\section{B. Instruments}

Considering the objective of the study, a number of instruments were prepared and used. We described and delineated these two self-report questionnaires in the following order:

1. Beliefs about Foreign Language Learning Inventory (BALL)

In this study Horwitz's (1987) beliefs about language learning inventory was administrated to investigate foreign language learners' beliefs on language learning. This questionnaire contains thirty- four items in five main areas: Difficulty of language learning (six items), Foreign language aptitude (nine items), Nature of language learning (six items), Learning and communication strategies (eight items), Motivation and expectation (five items). The Likert Scale items will use a scale ranging from 1(strongly disagree) to 5 (strongly agree). This questionnaire had an index reliability of Cronbach's Alpha $=.69$

\section{Trait Emotional Intelligence Questionnaire-Short Form (TEIQue-SF)}

According to Petrides and Furnham (2001, 2003), there are two types of emotional intelligence constructs, i.e., trait EI and ability EI. Trait emotional intelligence requires the use of self report questionnaires and relates to the realm of personality. Ability emotional intelligence is measured through maximum performance tests and pertains to the realm of cognitive ability. This 30-item self-report scale, developed by Petride and Fernham (2006), was designed to measure global trait emotional intelligence (trait EI). It is based on TELQue full form (Petride \& Fernham, 2003). Sample items include "I often pause and think about my feelings", "I tend to change my mind frequently", and "I am usually able to find ways to control my emotion when I want to". Respondents rate themselves on a 7-point Likert scale ranging from 'Completely Disagree' (number 1) to 'Completely Agree' (number7). The internal consistency reliability of the test was found to be high Cronbach's Alpha $=0.88$.

\section{PROCEDURE}

This study used correlational design and was conducted in two universities in Iran, University of Isfahan and Razi University. A total number of 138 EFL learners were randomly selected to participate in this study. A revised and translated Persian of two self-report questionnaires including Trait Emotional Intelligence-short form (TELQue-SF) and Beliefs about Foreign Language Inventory (BALLI) were employed. We explained the purpose of the study to all participants and assured them that their data would be confidential. It took participants approximately 30 minutes to complete questionnaires. To investigate the relationship between emotional intelligence and learners' beliefs about language learning, the Pearson Product Moment Correlation was used. To further identify whether emotional intelligence can predict learners' beliefs about language learning, Linear Regression was run. All statistical analyses in this study were submitted directly to SPSS (Statistical Package for the Social Science) version 21.

\section{RESULTS}

To report quantitative data of this study, including Emotional intelligence and learners' beliefs about language learning, both descriptive and inferential statistics were used to analyze the data (See, Table 1). Before addressing the research questions, we make sure the normality of distribution with the Kolmogoro-Smironov test.

TABLE 7.1

DESCRIPTIVE STATISTIC OF EMOTIONAL INTELLIGENCE AND BELIEFS ABOUT LANGUAGE LEARNING

\begin{tabular}{lllll}
\multicolumn{4}{c}{ DESCRIPTIVE STATISTIC OF EMOTIONAL INTELLIGENCE AND BELIEFS ABOUT LANGUAGE LEARNING } \\
\hline Research Variables & $\mathrm{N}$ & Mean & Std. Deviation & Sig \\
\hline Emotional & 138 & 4.04 & 0.599 & 0.306 \\
\hline $\begin{array}{l}\text { Learne' beliefs about language } \\
\text { learning }\end{array}$ & 138 & 4.13 & 0.587 & 0.418 \\
\hline
\end{tabular}


The first research question of this study concerned whether there was a significant relationship between emotional intelligence and learners' beliefs about language learning. To answer this question, Pearson Product Moment Correlation was conducted on El and learners' beliefs scores. As revealed in Table 2, there was a significant and positive relationship between $\mathrm{El}$ and learners' belief about language learning $(\mathrm{P}<0.05)$.

TABLE 7.2

CORRELATION BETwEen EMOTIONAL INTELligenCE AND LEARNERS’ BELIEFs ABout LANGUAGE LEARNING \begin{tabular}{l|l|l}
\hline $\mathrm{N}$ & Pearson Correlation & Significance(two tailed) \\
\hline 138 & $854^{* *}$ & 0.00
\end{tabular}

\begin{tabular}{l|l|l|}
\hline 138 & $.854^{* * *}$ & 0.00
\end{tabular}

**Shows the existence of the significant relationship at the level of 0.05

To address the second research question of this study, linear regressions was run to find whether emotional intelligence can predict learners' beliefs about language learning. As reported in table 3, emotional intelligence can predict learners' beliefs about language learning.

TABLE 7.3

PREDICTION OF LEARNERS’ BELIEFS ABOUT LANGUAGE LEARNING BY EMOTIONAL INTELLIGENCE

\begin{tabular}{l|l|l|l|l}
$\mathrm{R}$ & $R^{z}$ & $\mathrm{~F}$ & $\mathrm{Sig}$ & $\mathrm{B}$ \\
\hline 0.854 & 0.729 & 356.98 & 0.000 & 0.874 \\
\hline
\end{tabular}

As revealed in table 3, emotional intelligence can predict approximately 0.73 of variance in learners' beliefs about language learning $\left(R^{2}=0.729\right.$, Sig=0.00).

\section{CONCLUSION AND PEDAGOGICAL IMPLICATIONS}

Based on the first and second research question of this study, interestingly enough, emotional intelligence yields positive and significant relationships with learners' beliefs about language learning. Furthermore, emotional intelligence can predict learners' beliefs about language learning. The positive relationship between emotional intelligence and learners' beliefs about language learning in this study also lends support to the findings by Mayer \& turner (2002) who found that emotions are intertwined in teachers' instructional responses and students' beliefs and action. According to Ellis (2008), learners hold beliefs not just about the cognitive aspects of language and language learning but also about affective aspect. Besides, knowing one's emotion and motivating oneself in Goleman's (1995) EI model facilitate learners' beliefs about language learning. In this study a question may arise as how does emotional intelligence play a fundamental role on beliefs of EFL learners towards language learning. This question may be acknowledged if one ponder over at least two crucial issues: 1) in keeping with those reported by Aragao (2011), learners' emotions including worry, shyness, lack of self-confidence and fear may affect their beliefs towards language learning. Making aware of one's and others' emotions helps learners to cope with emotional obstacle that may influence on learners' beliefs towards language learning, and 2) with regard to EFL learners' beliefs, we grasp the fact that changes in learners' emotions can both promote and impede learners' beliefs towards language learning. Considering emotional aspects of language learning and teaching help teachers understand and manage learners' emotional intelligence and provide opportunity for EFL learners to foster positive beliefs towards language learning and remove emotional obstacles that make learners having negative beliefs towards language and learning environment. The findings of this study are in line with those reported by Mendez López (2011) who reported that "supporting students' emotions in language learning classroom can help learners to cope with feeling inherent to language learning experiences and to the development of a positive attitude towards themselves language learners" (p.44). .So, one of paramount dilemma in realm of education is that to what extent affective factors influence learner's beliefs towards language learning. Broadly speaking, understanding and recognizing one's and others' emotions enable both instructor and learner come down to the importance of applying emotional intelligence program in increasing learners' beliefs about language learning.

The information gathered by this study will likely help instructors better understand the interplay of emotional intelligence and learner's beliefs about language learning. The result of this study may provide the educators with a better understanding of the influence of emotional intelligence on the learners' beliefs about language learning. Furthermore, this study will also indicate that emotional intelligence has outstanding potential as a mediator of learners' positive beliefs about language learning. The findings of his study may suggest that instructors need to be aware of learners' beliefs about language learning. Making aware of learners' beliefs helps teachers and instructors to promote positive beliefs and also come down the negative beliefs of EFL learners that inhibit learning. Teachers can help learners feel comfortable speaking in the classroom with other classmate by providing them positive feedback and nonthreatening environment.

\section{LIMITATION OF THE STUDY}

Some limitations of the study must be acknowledged. Firstly, this study doesn't take age and gender in to account, more studies are called to generalize the result across different variables like age and gender. Secondly, this study doesn't take in to account a large sample of EFL learners. To select a large sample size, we could yield reasonable 
results than they are now. Thirdly, this study only examines the relationship between emotional intelligence, learners' beliefs about language learning and it doesn't indicate the causality between aforementioned variables. Finally, this study employed self-report questionnaires to investigate the relationship between emotional intelligence and learners' beliefs about language learning. Further study can be conducted to use different data collection methods such as classroom observation, video tape recording, and checklist to explore such relationship.

\section{REFERENCES}

[1] Aragao, R. (2011). Beliefs and emotion in foreign language learning. System, 39, 302-313.

[2] Arnold, J. (1999). Affect in language learning. Cambridge: Cambridge University Press.

[3] Bar-On, R. (1997). Bar-On emotional quotient inventory: User's manual. Toronto: Multi-Health Systems.

[4] Barcelos, A. M. F. (2003). Researching beliefs about SLA: A critical review. In beliefs about SLA: New Research Approaches, edited by Paul Kalaja and Ana Maria Barcelos. New York: Springer

[5] Bernet, E. (2008). Beyond beliefs: psycho- cognitive, sociocultural and emergent ecological approaches to learner perceptions in foreign language acquisition, Asion EFL Journal, 10 (3), 1-23.

[6] Carmeli, A., \& Josman, Z.E. (2006). The relationship among emotional intelligence, task performance and organizational citizenship behaviours. Human Performance, 19, 403-419.

[7] Cheng, Y. (2001). Learners' beliefs and second language anxiety. Concentric: Studies in English Literature and Linguistic, 27 (2), 75-90.

[8] Cohen, J. (1999). Educating minds and hearts: Social emotional learning and the passage into adolescence. New York: Teachers College Press

[9] Ellis, R. (2008). Learner beliefs and language learning. Asian EFL Journal, 10, 7-25.

[10] Extremera, N., \& Fernandez- Berrocal, P. (2006). Emotional intelligence as predictor of mental, social and physical health in university students. The Spanish Journal of Psychology, 9 (1), 45-51.

[11] Fisher, L. (2013). Discerning change in young students' beliefs about their language learning through the use of metaphor elicitation in the classroom. Research Paper in Education, 28 (3), 373-392.

[12] Garrett, P., \& Young, R. (2009). Theorizing Affect in Foreign Language Learning: An Analysis of one Learner's Responses to a Communicative-Based Portuguese Course. The Modern Language Journal, 93, 209-226.

[13] Goleman, D. (1995). Emotional intelligence: Why it can matter more than IQ. New York: Bantam Books.

[14] Goleman, D. (1998). Working with emotional intelligence. New York: Bantam.

[15] Horwitz, E. K. (1985). Using student beliefs about language learning and teaching in the foreign language methods course. Foreign Language Annals, 18, 333-340.

[16] Horwitz, E. K. (1987). Surveying student beliefs about language learning. In A. Wenden \& R. Rubin (Eds.), Learner strategies in language learning. 119-129. London: Prentice Hall International.

[17] Horwitz, E. K. (1988). The beliefs about language learning of beginning university foreign language students. The Modern Language Journal, 72 , 283-94.

[18] Huang, S. C., \& Tsai, R. R. (2003). A comparison between high and low English proficiency learners' beliefs. ERIC Document Reproduction Service No. ED 482579.

[19] Li, S., \& Liang, W. (2012). The dynamic nature of learner beliefs: the relationship between beliefs about EFL learning and proficiency in a Chinese context, Asian EFL Journal, 14 (1), 177-211.

[20] Méndez López, M. G. (2011). The motivational properties of emotions in foreign language learning. Appl. Linguist. Journal, 13 (2), 43-59.

[21] Mantle-Bromley, C. (1995). Positive attitudes and realistic beliefs: Links to proficiency. The Modern Language Journal, 79 , 372-386.

[22] Martins, A., Ramalho, N., \& Morin, E. (2010). A comprehensive meta - analysis of the relationship between emotional intelligence and health. Personality and individual differences, 49, 559-564.

[23] Mayer, J. D. \& Salovey, P. (1997). What is emotional intelligence? In P. Salovey \& D. J. Sluyter (Eds), Emontional development and Emotional Intelligence: Educational Implications: 3-31. New York: Basic Books.

[24] Mayer, D., K \& Turner, J. C. (2002). Discovering emotion in classroom motivation research. Educational Psychologist, 37, 107-114.

[25] Micooli, L. S. (1997). Learning English as a foreign language in Brizil: a joint investigation of learners' experiences in University classroom. (Unpublished doctoral dissertation). Ontario Institute for studies in Education, University of Toronto.

[26] Micooli, L. S. (2000). A deeper view of EFL learning: students' collective classroom experiences. Claritas 6 (3-4), $184-204$.

[27] Payne, W. L. (1986). A study of emotion: Developing emotional intelligence: self intelligence; relating to the fear and desire. Dissertation Abstract International, 47, 203 A University microfilm No, AA 8605928.

[28] Petride, J. K.V., Furnham, A.(2001).Trait emotional intelligence :Psychometric investigation with reference to established trait taxonomic. European Journal of Personality 15, no. 6:425-48.

[29] Petrides, K.V., \& Furnham, k. (2003). Trait emotional intelligence:Behavioural validationint wo studies of emotion recognition and reactivity to mood induction. European Journal of Personality 17(1), 39-57.

[30] Petride, K.V., Frederickson, N., \& Furnham, A. (2004). The role of trait emotional intelligence in academic performance and deviant behavior at school. Personality and Individual Differences, 36(2), 277-293.

[31] Petride, K.V., Futnham, A. (2006). The role of trait emotional intelligence in a gender- specific model of organizational variables. Journal of Applied Social Psychology, 36, 552-569.

[32] Pishghadam, R. (2009). A quantitative analysis of the relationship between emotional intelligence and foreign language learning. Electronic Journal of Foreign Language Teaching, 6(1), 31-41.

[33] Salovey, P. \& Mayer, J. (1990). Emotional intelligence . Imagination, Cognition, and Personality. 9, 3,185-211. 
[34] Shao, K.Q., Yu, W., \& Ji, Z.M. (2013). The relationship between EFL students' emotional intelligence and writing achievement. Innovation in language learning and teaching, 7(2), 107-124.

[35] Simon, E., Taverniers, M. (2011). Advanced EFL learners' beliefs about language learning and teaching: A comparison between grammar, pronunciation and vocabulary. English Studies, 92(8), 896-92.

[36] Sakui, K., \& Gaies, S. J. (1999). Investigating Japanese learners' beliefs about language learning. System 27(4), 473-92.

[37] Stottlemeyer, B .G. (2002). An examination of emotional intelligence and its relationship to academic achievement and the implications for education, Doctoral dissertation, Texas A\& M University Kingsyilla. UMI NO, 3043592.

[38] Vandervoort, D. J. (2006). The importance of emotional intelligence in higher education. Current Psychology, $25(1)$, 4-7.

[39] Vanderzee, k., Thijs, \& M., Schakel, k. (2002). The relationship between emotional intelligence with academic intelligence and the big five. European Journal of Psychology, 16(2), 103-125.

[40] Wenden, A. (1987). How to be a successful language learner: Insights and prescriptions from L2 learners. In A. Wenden \& J. Rubin (Eds.), Learner strategies in language learning (pp. 103-117). London: Prentice Hall.

[41] Wenden, A. L. (1999). An introduction to metacognitive knowledge and beliefs in language learning: Beyond the basics. System, 27, 435-441.

[42] Yang, N. D. (1992). Second language learners' beliefs about language learning and their use of learning strategies: A study of college students of English in Taiwan. Dissertation Abstracts International, 53(08), 2722A. (UMI No.9225771).

[43] Yang, N. D. (1999). The relationship between EFL learners' beliefs and learning strategy use. System, 27(4), 515-35.

[44] Yoshiba, R. (2013). Conflict between learners' beliefs and actions: speaking in the classroom. Language Awareness, 12 (1), 371-388.

[45] Zalesne, D. \& Nadvorney, D. (2011). Why don't get it? Academic intelligence and the under-prepared student as other. Journal of Legal Educational, 61(2), 264-279.

Zahra Ghanadi is an MA student in Applied linguistics at the University of Isfahan, Iran. Her interest includes second language acquisition and cognitive aspect of language and learning.

Saeed Ketabi has a PhD in Applied linguistics from University of Cambridge, England and is currently teaching ELT courses at the University of Isfahan, Iran. His research interests include English teaching methodology and material development. 